\title{
Early Warning to Banking Crises in the Dual Financial System in Indonesia: The Markov Switching Approach
}

\author{
Irfan Nurfalah \\ Bank Negara Indonesia Syariah \\ Aam Slamet Rusydiana \\ SMART Consulting Indonesia \\ Nisful Laila and Eko Fajar Cahyono \\ Faculty Economics and Business, Airlangga University, Indonesia
}

\begin{abstract}
This research aims at detecting early indicators that cause conventional banking and Islamic banking crises, identifying the longest crisis period for both types of banks, and comparing the stability between the two kinds of banks. The method used is the Markov Switching Vector Autoregressive (MS-VAR) approach. This study uses secondary data obtained from official sources and in monthly form from January 2004 to March 2017. The results show that Islamic banking is more stable against internal and external shocks than conventional banking. Z-score for Islamic banking is higher $(11,933)$ than the Z-score for conventional banking $(11,679)$. The longest crisis period for conventional banking was around April 2013 - March 2017 while for Islamic banking was around January 2008 - October 2008.
\end{abstract}

Keywords: Early warning, Banking crises, Markov switching approach.

KAUJIE Classification: L27, L4 


\section{Introduction}

One of the critical indicators in an economy is the bank's stability because the bank is the heart of the economy. Bank failure will cause a crisis and a recession in the economy which, in turn, will reduce the welfare of the community. Kaminsky, Lizondo, and Reinhart (1998, p. 15) define the banking crisis as a situation in which the attack to an exchange rate system causes a sharp depression in the exchange rate, or it can also cause a sharp decrease in the international reserves or even the combination of both. According to Frankel and Rose (1996, p. 351) a financial crisis is a major change to some indicators of the potential or actual value of a currency.

Islamic banks have arisen as competitors of the conventional banks in a share of the economy. Studies of the stability of the two bank types are numerous and show varying results. Some say that Islamic banks are more stable and robust in a crisis economy compared with conventional banks while, in contrast, others have stated that there is no significant difference between the robustness and stability of conventional banks and Islamic banks.

The financial crisis in 1997-1998 which occurred in Asian regions was marked by the decrease of the exchange rate of Thailand's Baht to the American Dollar, which reached $-54 \%$. This financial crisis spread to some other regions in Asia as well such as South Korea, Malaysia, Singapore and Indonesia. Won depreciation to the US Dollar was at $-48 \%$, Malaysian Ringgit depreciated at $-40 \%$ to the US Dollar and Singaporean Dollar depreciated at $-19 \%$ (Suta \& Musa, 2003, p. 7). In Indonesia, the exchange rate for Rupiah/USD was at Rp. 2,500 in 1997 and in the crisis period the exchange rate hit the bottom at Rp. 16,500/USD. The depreciation of the Rupiah's exchange rate caused the development of Indonesian economy to reach a negative figure of $-13.1 \%$ in 1998 .

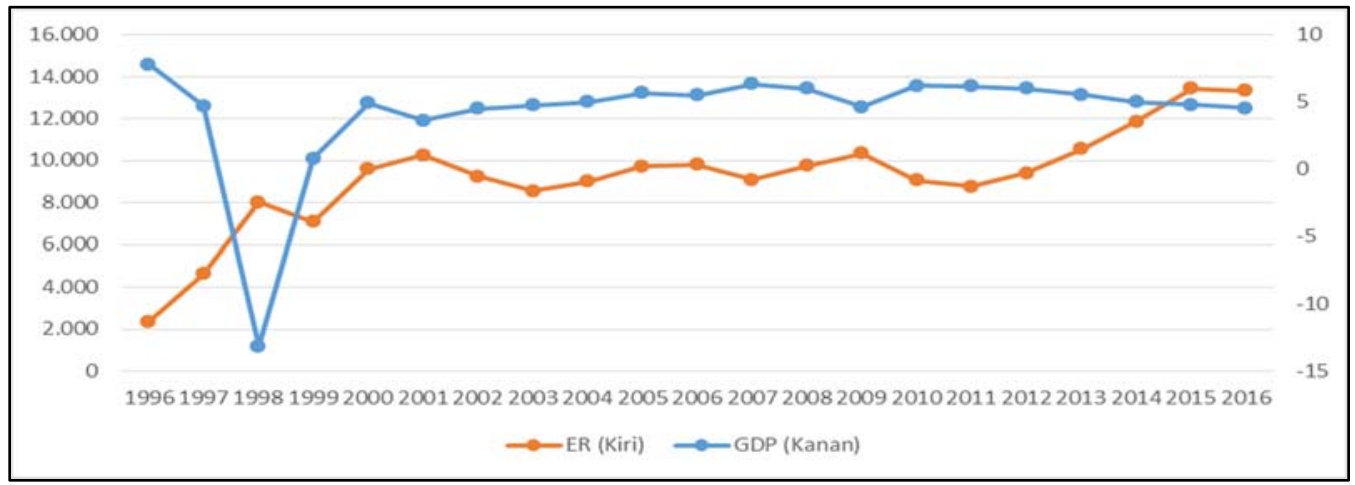

Source: IMF and World Bank, modified by the authors

Figure (1) Rupiah Exchange Rate and Economy Development 1996 - 2016

The crisis of the Rupiah exchange rate in 1998 should have been overcome by the banking sector by increasing the rate of interest. Overnight call rates increased to $81 \%$ and the rate of SBI interest climbed from $12 \%$ to $30 \%$. However, that increase in the interest rate could not re-stabilize the Rupiah exchange rate because there was no protection of unhedged foreign exchange exposure trying to buy the Dollars. In the end, the combination of depreciation of Rupiah exchange rate, the high rate of interest, the increased demand for Dollars and the increasing problems of loanees who had huge debts caused big problems which led to the banking crisis (Suta \& Musa, 2003, p. 9).

According to the news quoted from the website of Kontan, dated August 9, 2016, Dupla Kartini reported that the depreciation of the rupiah suddenly rocked the banking world, because the bank hid the impact that was not visible to the public. The rapid growth in the banking sector of Indonesia started from the end of 1988 when, at that time, the government of President Suharto introduced laws on the deregulation of 
banks. This narrative provided relaxation for the general public to establish a bank. With this regulation, people and parties with 1 billion Rupiah capital could establish their own bank. This regulation resulted in the loosening of the monetary authority's control. Many banks relied on short-tenured foreign currency (forex). Unfortunately, most of the loans were not obtained by hedging or hedging mechanisms. Also, a fierce competition fueled banks to lend to risky businesses, such as property. Another impact that was a result of the deregulation of banking was that there were a lot of bad loans from private banks because of the concentration of credit to the group. According to the annual report of Bank Indonesia (BI), 1998, the amount of non-performing loans in the national banking sector reached Rp 10.2 trillion as of April 1997; up 7.7\% compared to the end of 1996. When the Rupiah exchange rate fell in the face of foreign currency debt, banks experienced liquidity difficulties. Bank Indonesia as the central bank at that time enforced monetary tightening by terminating the transaction of Money Market Securities (SBPU) and increasing the interest rate of Bank Indonesia Certificates (SBI). The monetary tightening caused banks to struggle. With the cessation of funds from BI, interbank lending rates soared. Banks had to compete for public funds by increasing deposit interest rates. This caused further liquidity difficulties and increased debit balance in the clearing system of Bank Indonesia (Kartini, 2016).

The repetitive nature of the crises happening in many countries and destructive impacts to the economy have led researchers to study the initial cause of the crises or early warning indicators of the cause of the crises. Research done by Abimanyu and Imansyah (2008, p. 75), using the signal model and average crisis index plus 2 standard deviations, shows that the financial crises happening in Indonesia in the period of 1970-1997 resulted in crises occurring as many as four times, i.e., November 1978, April 1983, September 1986 and August 1997. This finding is also corroborated by Goldstein, Kaminsky, and Reinhart (2000) and Edison (2000).

Research on the stability of Islamic banks is prolific, and among the many, the one conducted by Ibrahim and Rizvi (2017, p. 77) states that large Islamic banks are more stable than a small size Islamic bank. They also revealed factors that influence the stability of Islamic banks such as the existence of regulation of capital (to regulate other banks).
The performance of conventional banks and Islamic banks has been compared in many studies. Doumpos, Hasan, and Pasiouras (2017, p. 513) compare the performance of Islamic banks, conventional banks and banks with Islamic banking window units. They use index power established by financial criteria and cover some aspects such as capturing bank capital strength, asset quality, earnings, liquidity, and management quality in controlling expenses. Results show that there is no significant difference between the performance of Islamic banks and conventional banks on the Asian continent. Mean-while in the Middle East, Senegal, and North African countries, the results showed that Islamic banks are more superior. Index Financial power affected many factors such as effectiveness of government and corruption.

A measure of the stability of Islamic banks is to examine the behavior of Islamic banks taking risks in circumstances of crisis. Ibrahim and Rizvi (2018, p. 81) state that during the crisis period, financing in Islamic banks is higher than financing in conventional banks. However, they find no evidence indicating any difference between the amount of current deposit growth before and after the crisis period. They conclude that there is no indication suggesting that Islamic banks exhibit excessive risk-taking in times of stress. This statement is evidence that Islamic banks promote financial stability and, in turn, the stability of the economy.

Statements about the stability of Islamic banks are still regularly debated. Besides proponents of the stability of Islamic banks, there are others who claim that Islamic banks are as stable as conventional banks. A study conducted by Alandejani, Kutan, and Samargandi (2017, p. 135) finds that the level of failure of Islamic banks is higher than the level of conventional bank failure. This research uses the discrete-time procedure model or the complementary $\log -\log$ model. The results of the study show that for the all-banks-pooled model the hazard rate increases with Islamic banks. Furthermore, the analysis of each bank type reveals that the effect of explanatory variables on survival time differs between Islamic and conventional banks. For instance, increasing the net interest margin ratio causes the hazard rate in Islamic banks to rise, whereas this rate is lowered in conventional banks. Among the macro-level variables, a higher inflation rate leads to a higher hazard 
rate; improving the regulatory quality corresponddingly reduces the hazard rate of survival time in the banking sector.

Research about default bank risk has been done by Saeed and Izzeldin (2016, p. 127) who examined the relationship between efficiency and default risk in Islamic banks (IBs) and conventional banks (CBs) in Gulf Cooperation Countries (GCC) and three nonGCC countries over the period 2002-2010. Their analysis shows that the relationship between profit efficiency and default risk in banks across the sample, for CBs and for the GCC, is such that a decrease in default risk is associated with lower efficiency levels.

Research on the current state of Islamic banks after the crisis was conducted by Farooq and Zaheer (2015, p. 1) using data from Pakistan, where both conventional and Islamic banks operate simultaneously. He investigates the behavior of Islamic banks and conventional banks when financial panic occurs. The research showed that Islamic banks are less prone to deposit withdrawal during financial panics, both unconditionally and after controlling for bank characteristics. The Islamic branches of banks that have both Islamic and conventional operations tend to attract (rather than lose) deposits during panics, which suggests a role for religious branding. The results also indicate that Islamic bank's financing also increases during crises in Pakistan.

Trad, Trabelsi, and Goux (2017, p. 44) state that the security of Islamic banks is affected by profitability and inflation in the Middle East and North African countries. It is observed that inflation exerts an adverse effect on the bank's performance when it increases the profitability measured by the return on assets (ROA). However, it has a negative and a significant effect on return on equity (ROE). This study differs from previous contributions in that it tested the hypothesis of determinants of bank profitability and stability for both conventional and Islamic banks in the MENA region.

Based on the information in the previous paragraphs it is known that there is variation in results comparing the stability of Islamic banks and conventional banks. In this context, this research attempted to investigate further the stability of Islamic banks vs conventional banks in Indonesia where both types of banks operate simultaneously in a dual banking system.
The importance of forecasting banking crisis has been presented by some experts such as Papanikolaou $(2018$, p. 127) who states that many banks have failed and received help financially when the financial crisis occurred. The effort in rescuing troubled banks is twice the impact of bank failure from the explosion of public debt in many economies. Hence, it is essential to build an early warning system for banking crises.

Tanaka, Kinkyo, and Hamori (2016, p. 118) state that studies about early warnings are very useful for indicating vulnerability about financial crises and could be used for creating a reliable financial safety net. They cite some scientists who have studied early warning systems previously such as Frankel and Rose (1996) and Kaminsky et al. (1998).

The importance of an early warning system about banking crisis was put forward by Kimmel, Thornton Jr., and Bennett (2016, p. 190). They state that each party in the banking industry wants to protect their own interests. Bank regulators want to prevent failures from occurring and investors want to keep from losing their money. Hence, regulators and researchers want to be able to predict bank failures before they occur and they have typically turned to early-warning systems (EWS) for this purpose.

Ascarya (2015, p. 109) studied the financial crises happening in the dual-banking system in Indonesia by using Analytical Network Process. The results show that the roots to the financial crises from Islamic economic perspective are: social and political instability (external factor), speculation and hedonism (misbehavior), ineffective fiscal system (unsustainnable fiscal system), fractional reserve banking system, interest, and fiat money (unstable monetary system), corruption, and the wrong man in the wrong place (poor governance). These main causes should be removed gradually in order to systematically and gradually improve the stability of the financial system so that financial crises will not reappear again and again in the future.

Shah and Bhutta's research (2016, p. 32) finds that the causes for the crises of conventional banking are bad high-cost credits by big-money loanees and that the conventional banks are not facilitating loans on a small scale. Moreover, Yang $(2017$, p. 4) states that the 2008 crises happened because of the bubble 
economy in which the goods traded were over their intrinsic value. The impact of the crises was the sharp decrease of export values in Asia (Brooks, Kurmanalieva, \& Yang, 2016, p. 340).

Other research related to early warning systems and banking crises was done by Hamdaoui (2016), Lang and Schmidt (2016), Caggiano, Calice, Leonida, and Kapetanios (2016), Dabrowski, Beyers, and de Villiers (2016), Guleva (2016), Stolbov (2015), and Vermeulen et al. (2015).

Hamdaoui (2016, p. 114) suggests the use of a multinomial logit model based on Bayesian Model Averaging instead of conventional multinomial and binary models The empirical results of his research show that for a set of 49 developing and developed countries, the model would have correctly predicted the vast majority of crises. In another research, Stolbov (2015, p. 553) examines a wide range of potential predictors of 25 international banking crises that broke out in 2007-2011 on the basis of crosssectional logit models and binary classification tree. The major determinants of the crises arise from an excessive credit depth and illiquidity of the banking sector.

After knowing how important an early warning about crisis failure in banking is, the way to measure the system is also important. One of the best ways to detect bank failure is to use Markovich Switching Method. Guérin and Leon (2017, p. 46) stated that the Markovich method is an essential method because it combines good forecasting with method forecasting derived from individual models; Markovich Switching Methods is considered as the best method for data of a discrete nature as it focuses on target variables. They used the Markovich method to predict recession periods in the USA.

There are several research objectives to be achieved in this research. The first objective is to apply the Markov Switching method and identify the early indicators of the financial crisis in conventional and Islamic banking. The second goal is to determine the most extended period of crisis in conventional banking and Islamic banking based on the Markov Switching method, and the last purpose is to know which banking industry (conventional or Islamic) has better resilience in the face of crisis
The rest of this paper is structured as follows. Section two consists of the literature review. In section 3 we describe the data and methodology comprising the type of data and the model of analysis used. The fourth section presents and discusses the results of the research. The conclusions and recommendations are given in the last section.

\section{Literature Review}

A currency crisis is one of the main reasons for financial crises. The literature on currency crises mentions three generations of models to explain the causes of currency crises. There are also numerous other models that deal with single cases of crises. These represent alternative explanations for the causes of currency crises that are outside the conventional 'generational directions'. Following is a brief description of these models as described by Krznar (2004, pp. 3-9).

\section{(i) First Generation Model}

The first generation of crisis models are the speculative attack models. According to this theory a crisis of exchange rate occurs due to a balance of payments crisis experienced by one country with an open economy, of small size, and applying a fixed exchange rate. The theory was introduced by Salant and Henderson (1978), which was later developed by Krugman (1979), in which there is a balance of payments crisis and the fall of currency exchange rates due to the expansion of domestic credit by the central bank in a manner which is inconsistent with the exchange rate targets.

\section{(ii) Second Generation Model}

The second generation crisis models are also known as exit clause models. It explains that the crisis is due to a balance of payments crisis that occurs in the midst of strong economic indicators. The crisis is also motivated by countries that adopt a fixed exchange rate system. Second generation crisis model was developed by Obstfeld (1996). In the model, the central role of expectations and failure of coordination among creditors causes the crisis despite the economic fundamentals of a country being healthy. When investors speculate whether the government will control the exchange rate or not, then this model will show a balance where the speculative attack will be created by itself. According to Ozkan and Sutherland (1995), the monetary authority would not 
agree to keep the exchange rate at a high rate in speculative attacks if the unemployment rate is high as this will lead to even more unemployment.

\section{(iii) Third Generation Model}

The third generation crisis models state that the cause of the financial crisis is due to the contagion effect. This crisis spreads through trade relationships when depreciation takes place in a country declining in competitiveness with other countries. Interdependence can provide a role for a disaster when a country's inability to pay off foreign debt forces foreign creditors to repeal loans in other countries. Ali (2007, p. 107) says that this model focuses on the balance sheet effects associated with currency devaluation. Where banks and firms in developing countries have currency discrepancies, they make loans with foreign currency and provide loans in local currency. So that will cause credit risk due to the devaluation of the currency exchange rate.

\section{(iv) Other Models}

One alternate model is the Kindleberger-Minsky model that explains the three stages of a financial crisis: mania, panic, and collapse. Desire (mania) is an upswing period in the business cycle when market participants restructure their assets such that they increase the share of real and financial assets. Panic is characterized by the influence of encouragement and competition in the transformation of financial and tangible assets into the most liquid assets. Collapse is the final stage of the process (Imansyah, 2008, p. 28).

Saqib (2002, p. 11) argues that the crisis may begin from outside the financial system such as war, politics, and other factors that can have a substantial impact on expectations of economic growth and decline in one sector.

The economic crisis in Islamic history occurred in the $15^{\text {th }}$ century when the Islamic government was in Cairo, Egypt. Al-Maqrizi said that there were three major causes of the financial crisis in Egypt. First, government, courts and administrative posts are obtained through bribery. Second, the cost of land was very high leading to higher production cost, with the land rent price increasing ten times. Third, the decline in the exchange rate and supply falls that are not restricted. From these three causes, according to AlMaqrizi (as cited in Islahi, 2013, p. 81), the last cause had the most significant impact on the financial crisis in Egypt at the time.
Meera (2004) mentions that there are several adverse effects caused by the ribā-based economic system, namely:

(a) Interest requires that economic growth is endless even when the standard of living is constant.

(b) Interest encourages competition among economic actors.

(c) Interest concentrates wealth only in the hands of a small minority (the rich) by taking taxes from the majority (middle-poor).

He also mentions that paper money that is not backed up by gold leads to speculation where the exchange rate between countries has a difference that gives rise to profits.

\section{Fractional Reserve Banking System}

Fractional reserve banking system (FRBS) means that banks are only required to keep reserves in a certain percentage of deposited funds. The minimum mandatory reserves of banks are fixed at around 5\%$20 \%$. With this system, banking can create other types of fiat money, namely bank money (demand deposits, including electronic payments) through the creation of multiple deposits (multiple deposit creation). In this case, money is created when the bank provides loans (Ascarya, Achsani, \& Yumanita, 2007).

Fractional reserve banking system will provide a significant profit to commercial banks by providing loans. The advantage gained in the form of seigniorage is the cost of money creation by lending which is smaller than the real nominal value of money lent. For example, the customer keeps the money, say Rp. $1,000,000$, in Bank A. In the presence of FRBS at $8 \%$, for example, the money that can be disbursed is Rp. 920,000. The second customer borrows cash from Bank A and then deposits all of his loan at Bank B. With $8 \%$ reserve, or Rp. 73,600 (8\% x 920,000), the amount of money that Bank B can lend is reduced to Rp. 846,400 .

Thus, the money creation process undertaken by commercial banks through the fractional reserve instrument will continue until the number of incoming reserves reaches Rp. 1,000,000 by the number of deposits made first. With the process of creating demand deposits by commercial banks that initially 
only amounted to Rp. 1.000 .000 , would become Rp.12,500,000 in the presence of FRBS at 8\% (Ascarya, Achsani, \& Yumanita, 2007).

\section{International Monetary System}

The international monetary system with its liberalization products spawned a policy whereby countries could use paper money in the absence of backed-up gold or real assets. This policy can be advantageous for the state benefitting from the seigniorage profit (the difference between the nominal value and the printing price of the currency). However, it turns out that behind the gain, the losses are more marked by rising commodity prices causing inflation and weakening the purchasing power of the people. The advantages are only for the more wealthy countries whose currencies are used as global currencies such as the US Dollar. The Americans get a very large seigniorage of international trade. Whereas the small countries whose currencies are weak and not convertible, only benefit from the printing of national banknotes. This situation causes persistent inflation and injustice, especially for the small and developing countries. The more a country's currency is used in international trade, the more profits are taken from the seigniorage (Ascarya, 2009, p. 5).

\section{Decoupling of the Real Sector and the Monetary Sector}

The function of money in trade is as a medium of exchange and not as traded goods. Money as a means of exchange is used to facilitate transactions in the real sector, so all existing sales are for the actual industry. But now it is money being traded in the money market, debt sold on the derivatives market, and many other monetary goods can be purchased which are not backed by tangible assets. Moreover, it is supported by a system of interest, where profits have been determined at the beginning of the transaction, so now the monetary sector is growing faster than the real sector can grow creating a gap between the two industries (Ascarya, 2009, p. 6).

\section{Methodology and Data}

The research methodology includes information on the econometric model being studied and the steps involved in the research model. Then we explain the types and source of data being studied. Explanation about internal and external variables used and the model structure designed is given in the form of model equations. In addition, the methodology used in this research was the Markov Switching, which uses latent variable that follows the first derivative from two-stage Markov, which is

$\left\{\mathrm{S}_{\mathrm{t}}\right\}_{t=1}^{T} . \mathrm{S}_{\mathrm{t}}=1$

in the crises state and $\mathrm{S}_{\mathrm{t}}=0$ in the tranquil state.

\subsection{Type and Source of Data}

This research used secondary data gathered from official sources and from January 2004 to March 2017. The sources of the data are: Indonesian Banking Statistic provided by the Financial Service Authority of Indonesia; Islamic Banking Statistic provided by the Financial Service Authority of Indonesia and the Central Bureau Statistic, Indonesian Economy; Monetary Statistic provided by Bank of Indonesia; and International Financial Statistics (IFS) published by the IMF and Indonesian Trades Ministry. The profile of Islamic banks in Indonesia is as follows: As of December 2017, the number of Islamic commercial banks is 13 , the number of Islamic unit windows owned by conventional banks amounts to 22 , and the number of Islamic rural banks is 167 . Total assets held by Islamic commercial banks and Islamic unit windows owned by conventional banks amounted to 424,181 Billion rupiahs with 2189 offices and 55,746 employees. Islamic banks in Indonesia had distributed 44,696 billion rupiahs of financing to the community as of December 2017. Conventional banks' profile in Indonesia is as follows: As of December 2017, the total number of conventional commercial banks is 115 . Total assets owned by conventional commercial banks is $7,387,144$ Billion rupiahs with a total of 32,285 offices. Conventional banks in Indonesia have disbursed 32,285 billion rupiahs of financing for the community until December 2017. The data type is time series and the period of data is monthly.

\subsection{General Equations, Variables and Operational Definitions}

There are two models of general equations used in this paper, namely the equations for conventional banking and Islamic banking. The equation model is divided into two because each banking has a different system and the proxy variables for crises are different between the two banking systems. 
Table (1) General Equations of Research Model

\begin{tabular}{|c|c|}
\hline $\begin{array}{l}\text { Model 1: } \\
\text { Conventional }\end{array}$ & $\begin{aligned} \text { ZscoreK }_{t}=A_{0}+ & A_{1} B D K_{t-i}+A_{2} L D R_{t-j}+A_{3} C A R K_{t-k}+A_{4} C R K_{t-I}+A_{5} I R_{t-m} \\
& +A_{6} I P I_{t-n}+A_{7} I N F_{t-o}+A_{8} E X C_{t-p}+A_{9} C R E D O_{t-q}+A_{10} M 2_{t-r} \\
& +A_{11} C A G D P_{t-s}+\varepsilon_{t}\end{aligned}$ \\
\hline $\begin{array}{l}\text { Model 2: } \\
\text { Islamic Model }\end{array}$ & $\begin{aligned} \text { ZscoreK }_{t}=A_{0}+ & A_{1} B D S_{t-i}+A_{2} F D R_{t-j}+A_{3} C A R S_{t-k}+A_{4} C R S_{t-I}+A_{5} I R_{t-m} \\
& +A_{6} I P I_{t-n}+A_{7} I N F_{t-o}+A_{8} E X C_{t-p}+A_{9} C R E D O_{t-q}+A_{10} M 2_{t-r} \\
& +A_{11} C A G D P_{t-s}+\varepsilon_{t}\end{aligned}$ \\
\hline
\end{tabular}

Source: Author's modification.

The indicator used for the crises proxy is Z-Score. ZScore is the indicator used to measure the banking stability by adding the ROA and SER (Shareholder Equity Ratio) divided by the standard deviation from the ROA (Cihák \& Hesse, 2008, p. 25). In addition, the internal indicators used in this research are LDR,
CRK, BDK, and CARK for conventional banking and FDR, CRS, BDS and CARS for Islamic banking. Meanwhile, the external indicators used are INF, IR, IPI, EXC, M2, CREDO and CA/GDP. The definitions of the proxy crises indicator, internal indicators and external indicators are presented in table 2.

Table (2) Summary of Indicators Used in the Research

\begin{tabular}{|c|c|c|c|}
\hline \multicolumn{2}{|c|}{ Z-Score } & \multicolumn{2}{|c|}{ Banking Stability Indicator } \\
\hline \multicolumn{2}{|c|}{ Z-ScoreK } & \multicolumn{2}{|c|}{ Conventional Banking Stability Indicator } \\
\hline \multicolumn{2}{|c|}{ Z-ScoreS } & \multicolumn{2}{|c|}{ Islamic Banking Stability Indicator } \\
\hline \multicolumn{2}{|r|}{ Internal Indicators } & \multicolumn{2}{|c|}{ External Indicators } \\
\hline LDR & Loan to deposit ratio & INF & Inflation \\
\hline FDR & Financing to deposit ratio & IR & Interest rate \\
\hline CRK & Cash ratio (conventional banking) & IPI & Industrial production index proxy GDP \\
\hline CRS & Cash ratio (Islamic banking) & $\mathrm{EXC}$ & Exchange rate \\
\hline BDK & $\begin{array}{l}\text { Bank deposit } \\
\text { (conventional banking) }\end{array}$ & M2 & Money supply \\
\hline BDS & Bank deposit (Islamic banking) & CREDO & $\begin{array}{l}\text { Credit domestic } \\
\text { (The Proportion Percentage of GDP). }\end{array}$ \\
\hline CARK & $\begin{array}{l}\text { Capital adequacy ratio } \\
\text { (conventional banking) }\end{array}$ & $\mathrm{CA} / \mathrm{GDP}$ & $\begin{array}{lll}\text { Current account/GDP; } & \text { 3-monthly data } \\
\text { interpolated to be monthly } & & \\
\end{array}$ \\
\hline CARS & $\begin{array}{l}\text { Capital adequacy ratio } \\
\text { (Islamic banking) }\end{array}$ & - & - \\
\hline
\end{tabular}

Source : Author's Modification.

The indicator used for the crises proxy is Z-Score. The justification for using the $Z$ score as a valid measure for bank stability is discussed by Chiaramonte, Croci, and Poli, F. (2015) in their paper "Should we trust the Z-score? Evidence from the European Banking Industry". In the study, they investigate the accuracy of the Z-score, the proximity for bank soundness, on a sample of European banks from 12 countries over the period 2001-2011. Summarizing the results of their study they report:

Specifically, we run a horse race analysis between the Z-score and the CAMELS related covariates. Using probit and complementary log-log models, we find that the Z-score's ability to identify distress events, both in the whole period and during the crisis years (2008-2011), is at least as good as the CAMELS variables, but with the advantage of being less data demanding. Finally, the Z-score proves to be more effective when bank business models may be more sophisticated as it is the case for large and commercial banks. (p. 111)

\subsection{Research Methodology}

In order to explain the research methodology, we will discuss the definition of Markov Switching and the determination of the crises period. The elaboration is as follows: 


\subsubsection{Definition of Markov Switching}

The Markov Switching Model (also known as the regime switching model), is one of the most popular nonlinear time series models. This model involves multiple structures (equations) that can characterize the time series behaviors in different regimes. Regime is the term used to describe structural changes in time series data, i.e., a shift in the behavior of the time series due to some permanent change in the economy's structure. By permitting switching between these structures, the Markov Switching Model is able to capture more complex dynamic patterns (Kuan, 2002, p. 1; Piger, 2009, p. 191).

The variable used as the indicator for banking stability is the Z-Score $\left(y_{\mathrm{t}}\right)$. In this research, the Markov Switching model used is the multivariate model i.e. Model MS-VAR (Markov Switching Vector Auto Regression) which can be used as an alternative for time series linear model with constant parameter. According to Krolzig (1997, pp. 6-7), the general idea of this regime change model is that the parameter of the time series vector having dimension $\mathrm{K}\left\{y_{t}\right\}$ depends upon an unobserved regime variable $s_{t} \in\{1, \ldots, m\}$, which represents the probability of being in a certain regime. The conditional probability density of the observed $\left\{y_{t}\right\}$ is given by:

$p\left(y_{t} \mid Y_{t-1}, X_{t}, s_{t}\right)=\left\{\begin{array}{c}f\left(y_{t} \mid Y_{t-1}, X_{t} ; \theta_{1}\right) \text { if } s_{t}=1 \\ \vdots \\ f\left(y_{t} \mid Y_{t-1}, X_{t} ; \theta_{M}\right) \text { if } s_{t}=M\end{array}\right.$

in which $Y_{t-1}=\left\{y_{t-j}\right\}_{1}^{\infty}$ is the historical value of $y_{t}$ and $X_{t}$ is the exogen variable, and $\theta_{m}$ is the parameter vector in the regime $m$.

The regression model of Markov Switching can be defined as follows:

$y_{t}=\left\{\begin{array}{ccc}X_{t} \beta_{1}+u_{t}, & u_{t} \mid s_{t} \sim N\left(0, \Sigma_{1}\right) & \text { if } s_{t}=1 \\ & \vdots & \\ X_{t} \beta_{M}+u_{t}, & u_{t} \mid s_{t} \sim N\left(0, \Sigma_{M}\right) & \text { if } s_{t}=M\end{array}\right.$ in which $X_{t}$ is the exogen regressor matrix in the amount of $(K \times R)$ and $u_{t}$ is the Innovation processes. The most common form of MS-VAR process with order $p$ and regime $M$ is:

$$
\begin{aligned}
y_{t}= & v\left(s_{t}\right)+A_{1}\left(s_{t}\right) y_{t-1}+\cdots+A_{p}\left(s_{t}\right) y_{t-p}+u_{t}, \\
& u_{t} \mid s_{t} \sim N\left(0, \Sigma\left(s_{t}\right)\right)
\end{aligned}
$$

with the value of presample $y_{0}, \ldots, y_{1-p}$ staying constant.

There are some specifications for MS-VAR model which equate time series towards the regime changes. The notation commonly used for the MS-VAR model specification which shows the variable that changes towards the regime change is as follows:

M Markov-switching mean,

I Markov-switching intercept,

A Markov-switching autoregression parameter,

$\mathrm{H}$ Markov-switching heteroscedasticity.

For example, VAR with the regime change on the mean is known as process $\operatorname{MSM}(M)-\operatorname{VAR}(p)$

$$
\begin{array}{r}
y_{t}-\mu\left(s_{t}\right)=\sum_{k=1}^{p} A_{k}\left(y_{t-k}-\mu\left(s_{t-k}\right)\right) \\
+u_{t} u_{t} \mid s_{t} \sim N(0, \Sigma) .
\end{array}
$$

If the regime change happens on the intercept of $\mathrm{VAR}$, it is called process $\operatorname{MSI}(M)-\operatorname{VAR}(p)$

$y_{t}=v\left(s_{t}\right)+\sum_{k=1}^{p} A_{k} y_{t-k}+u_{t} u_{t} \mid s_{t} \sim N(0, \Sigma)$.

Meanwhile, for VAR with all of the parameters changing towards regime change is called $\operatorname{MSIAH}(M)$ $\operatorname{VAR}(p)$ which is shown in the model equation (5). Table 3 summarizes the different specification types of MS-VAR models.

Table (3) Regime Parameter MS-VAR

\begin{tabular}{|l|c|c|c|c|}
\hline \multicolumn{1}{|c|}{ Notation } & $\mu$ & $v$ & $\Sigma$ & $A_{i}$ \\
\hline $\operatorname{MSM}(M)-\operatorname{VAR}(p)$ & Change & - & Does not change & Does not change \\
\hline $\operatorname{MSI}(M)-\operatorname{VAR}(p)$ & - & Change & Does not change & Does not change \\
\hline $\operatorname{MSIH}(M)-\operatorname{VAR}(p)$ & - & Change & Change & Does not change \\
\hline $\operatorname{MSIAH}(M)-\operatorname{VAR}(p)$ & - & Change & Change & Change \\
\hline
\end{tabular}

$\mu$ : mean, $v$ : intercept $\Sigma$ : variation $A_{i}$ : autoregression parameter matrix. 


\subsubsection{Determination of Crises Period}

This research uses the latent variable which follows the first derivation from two-stage markov, which is $\left\{\mathrm{S}_{\mathrm{t}}\right\}_{t=1}^{T}$. The $\mathrm{S}_{\mathrm{t}}=1$ is the crises state and the $\mathrm{S}_{\mathrm{t}}=0$ is the tranquil state. Although in this model the $\mathrm{S}_{\mathrm{t}}$ is unobserved directly, the behavior of the dependent variable $\left(\mathrm{Y}_{\mathrm{t}}\right)$ is free from the $\mathrm{S}_{\mathrm{t}}$, and this is formulated as follows:

$$
Y_{t} S_{t} \stackrel{i i d}{\sim}\left(\mu_{S t}, \sigma_{S t}^{2}\right)
$$

State 0

Period t-1

State 1

$$
\begin{aligned}
& \text { State } 0 \\
& {\left[\begin{array}{cc}
P_{00}^{t} & P_{01}^{t}=\left(1-P_{00}^{t}\right) \\
\operatorname{Pr}\left(s_{t}=0 \mid s_{t-1}=0, x_{t-1}\right) & \operatorname{Pr}\left(s_{t}=1 \mid s_{t-1}=0, x_{t-1}\right) \\
=F\left(x_{t-1}^{t} \beta_{0}\right) & =1-F\left(x_{t-1}^{t} \beta_{0}\right) \\
P_{10}^{t}=\left(1-P_{11}^{t}\right) & P_{11}^{t} \\
\operatorname{Pr}\left(s_{t}=1 \mid s_{t-1}=1, x_{t-1}\right) & \operatorname{Pr}\left(s_{t}=1 \mid s_{t-1}=1, x_{t-1}\right) \\
=1-F\left(x_{t-1}^{t} \beta_{t}\right) & =1-F\left(x_{t-1}^{t} \beta_{t}\right)
\end{array}\right]}
\end{aligned}
$$

The dependent variable $\left(\mathrm{Y}_{\mathrm{t}}\right)$ used in this research is the Z-Score. In this MS model, the value of mean and the variant of $Y_{t}$ can change depending on the regime. The density from $\mathrm{S}_{\mathrm{t}}$ can be formulated as follows:

$$
f\left(\mathrm{Y}_{\mathrm{t}} \mid \mathrm{S}_{\mathrm{t}}\right)=\frac{1}{\sqrt{2 \pi \sigma_{\mathrm{St}}}} \exp \frac{\left[-\left(y_{t}-\mu_{\mathrm{St}}\right)^{2}\right]}{2 \sigma_{S t}^{2}}
$$

for $S_{\mathrm{t}}=0,1$

Latent variable from regime switching $\left(\mathrm{S}_{\mathrm{t}}\right)$ is acquired from the transition matrix of probability $\mathrm{P}_{\mathrm{t}}$ as follows:

\section{Period $\mathrm{t}$}

The $\mathrm{P}_{i j}^{t}$ is the probability of movement from the state $I$ in the period of $t-1$ to the state $j$ in the period of $t$, and $\mathrm{F}$ is the function of cumulative nominal of cdf component from the vector $k x 1 . \mathrm{X}_{\mathrm{t}-1}$ is the early warning indicator which can affect the transition chance.

To implement this model, a basic value is needed, which is $P_{1}^{1}=\operatorname{Pr}\left(s_{t}=1\right)$ which is also the unconditional probability to become state 1 in the period 1 . Treatment of the values depends on whether the $x_{t}$ is stationary or not. If the $x_{t}$ is stationary then the probability for long term is $P_{1}^{1}=s_{1}=1$ and is the function from $\left(\beta_{0}, \beta_{1}\right)$. Meanwhile, if the $x_{t}$ is not stationary then $P_{1}^{1}$ is an additional parameter which needs to be estimated. In practice, if the data for time periods are long enough then the function of likelihood will not be affected either by counting the function from $\left(\beta_{0}, \beta_{1}\right)$ separately or by defining fixed values. This will not make much difference.

The estimation procedure used is by maximizing the function of likelihood. The function of likelihood is measured by the iteration suggested by Hamilton (1990). By using the available information until the period of $\mathrm{t}$, we can create $\operatorname{Pr}\left(s_{t}=j \mid \Omega_{t} ; \odot\right)$, which is a conditional probability (filtered) from observation $\mathrm{i}$ resulting from regime $\mathrm{j}$, for $\mathrm{j}=1,2, \ldots, \mathrm{N}$. $\mathrm{N}$ is the number of state, which for this research is $\mathrm{N}=2$. Next the conditional probability is combined in the vector $(N x 1) \widehat{\xi_{t \mid t}}$.

The estimation can also be done by conditional probability (forecast) to become regime $\mathrm{j}$ in the period of $\mathrm{t}+1$ with available information until the period of $\mathrm{t}$, which can be formulated as $\operatorname{Pr}\left(s_{t}=\right.$ $\left.j \mid \Omega_{t+1} ; \odot\right)$, for $\mathrm{j}=1,2, \ldots, \mathrm{N}$. This probability estimation is combined in the vector $(N x l) \widehat{\xi_{t+1 \mid t}}$. Lastly $\Omega_{t}$ is noted as vector $(N x l)$ which has components as many as $\mathrm{j}$ and which is the density function of the equation (5). The probability is filtered and measured for each period of $t$ by doing the iteration in the following equation:

$$
\begin{aligned}
& \widehat{\xi_{t \mid t}}=\frac{\widehat{\xi_{t \mid t-1}} \mathrm{o} \Omega_{t}}{1^{\prime} \widehat{\xi}_{t \mid t-1} \mathrm{o} \Omega_{t}} \\
& \widehat{\xi_{t+1 \mid t}}=P_{t+1}^{\prime}{ }_{t+1} \widehat{\xi_{t \mid t}}
\end{aligned}
$$

The $\mathrm{P}_{\mathrm{t}}$ is the matrix of size $\mathrm{NxN}$ from the transition probability from period $t-1$ to period $t$ as it is presented in the equation (7), and $\mathrm{o}$ is the multiplication 
notation from each element. Equation (8) counts $\operatorname{Pr}\left(s_{t}=j \mid \Omega_{t+1} ; \odot\right)$ as the distribution ratio with $f\left(y_{t}, s_{t}=j \mid \Omega_{t+1} ; \odot\right)$ towards marginal distribution $f\left(y_{t}=j \mid \Omega_{t+1} ; \odot\right)$. The marginal distribution is obtained by adding up the combined distribution from the 2 states. Equation (8) shows that when the best estimation for the current state position is obtained, then it is not enough just multiplying the transformation of matrix $\mathrm{P}$ from the transition probability to get the estimation probability from each state in the next period.

\section{Findings and Discussion}

\subsection{Movement of Z-Score Variable}

The average movement between the Z-score of conventional banks and the Z-score of Islamic banks shows that the average of $Z$-score of Islamic banks is greater than the Z-score of conventional banks. This is caused by the increase in the bank assets, the low assets to loans and cost-to-income ratio as well as the increase in income diversity (income diversity $=$ $\left.1-\left|\frac{\text { net interest income - other operating income }}{\text { totaloperating income }}\right|\right)$ obtained by the Islamic banks (Cihák \& Hesse, 2008, p. 17). In the graph below it can be seen that the average of the Z-score of Islamic banks (11.933) is greater than the average of the Z-score of conventional banks (11.679). This finding is similar to the findings of Cihák and Hesse, (2008, p. 16). Theoretically and empirically, the finding proves that Islamic banks have a greater level of stability compared to the conventional banks, and this finding can also prove that the conventional banking system which applies the interest concept is more susceptible to crises compared to the Islamic banks which apply the system of profit-loss sharing (PLS).

Figure (2) Graph of Average ZscoreK and ZscoreS

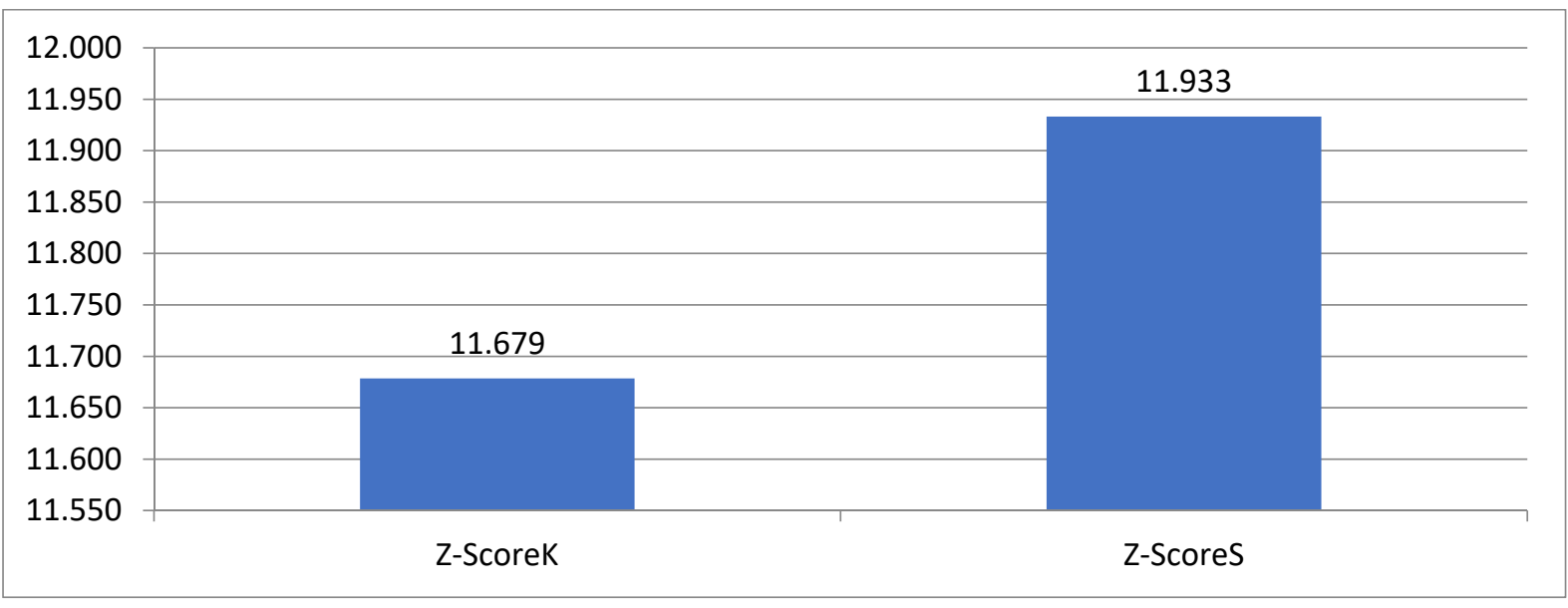

Source: Writer's modification.

The average figures between the Zscore $\mathrm{K}$ and the ZscoreS are not greatly different, which means there is a possibility that the average of both scores has no difference at all. Thus, to prove whether both scores have significant difference or not, we use the SPSS 17 software to run the differentiation test. The result is given in table 4 . 
Table (4) Differentiation Test between ZscoreK and ZscoreS

\begin{tabular}{|l|c|c|c|c|c|c|}
\hline & \multicolumn{5}{|c|}{ Test Value $=0$} \\
\hline & & & & & $95 \%$ Confidence Interval of the Difference \\
\hline & T & Df & Sig. (2-tailed) & Mean Difference & Lower & Upper \\
\hline ZscoreK & 21.053 & 131 & $\mathbf{. 0 0 0}$ & 11.70172 & 10.6022 & 12.8013 \\
\hline ZscoreS & 9.685 & 131 & $\mathbf{. 0 0 0}$ & 11.93312 & 9.4957 & 14.3705 \\
\hline
\end{tabular}

Notes: the bold printed is significant at real level 5\%.

It can be seen from the table that the significant value of ZscoreK and ZscoreS 0.000 is smaller than the real level 0.05 . It means that the null hypothesis stating that the average ZscoreK and ZscoreS are the same has been rejected, and thus the alternative hypothesis stating that the average ZscoreK and ZscoreS is not the same has been accepted. So, the conclusion from

the result of the differentiation test is that there is a difference between ZscoreK and ZscoreS; in other words, this has proved that ZscoreS which has higher average score than ZscoreK is more stable towards crises and ZscoreK is more susceptible towards crises compared to ZscoreS.

\subsection{The Results of Data Testing}

This research used Markov Switching Vector Autoregression (MS-VAR) method in which some tests were conducted. Those tests were the Stationary test, the Chow Breakpoint test, the Heteroskedastic test and the Partial Significance test. Further details about those tests are given below.

\subsubsection{Stationary test}

Time series data usually contains fluctuating data which are difficult to estimate. (Gujarati, 2003, p. 792). In order to estimate time series data, stationary data test with Augmented Dickey Fuller (ADF) and Phillips-Perron (PP) test needs to be done. The result of processing the data using Eviews software shows that variables of crises proxy of both ZscoreK and ZscoreX are stationary on the first different. Conventional micro banking variables consist of 4 variables; Bank Deposit (BDK), Capital Adequacy Ratio (CARK), Loan to Deposit Ratio (LDR) and Cash Ratio (CRK). BDK, LDR and CRK are stationary on the first different and CARK is stationary at level point. Islamic bank micro variables which are Capital Adequacy Ratio (CARS), Financing Deposit Ratio (FDR) and Cash Ratio (CRS) are stationary at level point and another one which is Bank Deposit (BDS) is stationary at first different. Finally, the macroeconomic variables which are interest rate (IR), inflation (INF), exchange rate (EXC), domestic credit (CREDO), money supply (M2), and current account/ gross domestic product (CA/GDP) are stationary on the first different and CA/GDP is stationary at level point. The data used in estimating this research was tested in stationary test and the results can be seen in the Appendices 1, 2 and 3.

\subsubsection{Chow Breakpoint test}

Chow Breakpoint test is used to find out if there are any economic shocks at certain periods during the study period. In this research Chow test is applied as the support of the estimation result of crises period. The result of processing the data by the author shows the result of Chow Break model of conventional bank is that the F-statistic is 2,137928 which is stationary at a real level of 5\% indicating that the null hypothesis claiming that there are not any structural shifts is rejected. It means that conventional model indicates structural shifts in the period of October 2016. For Islamic bank the F-statistic is 1,984528 which is significant at the real level of 5\%. It shows that the null hypothesis is rejected, meaning that there is a structural shift in the model and in the Islamic bank model the shift happened in the period of August 2005. Appendix 4 and 5 provide detail information for this.

\subsubsection{Heteroskedastic test}

Heteroskedastic test is undertaken to see if there is any inconstant variant. Applying this test gives results which are consistent, efficient and not biased that is why we apply this test to MS-VAR. It can be seen from table 4 that the significant value of ZscoreK and ZscoreS 0.000 is smaller than the real level 0.05. It means that the null hypothesis stating that the average ZscoreK and ZscoreS are heteroskedastic is not rejected. The result of heteroskedastic test with BreuschPagan-Godfrey test for conventionnal bank model 
shows probability $\mathrm{F}$ of 0.00001 which is smaller than the real level of $5 \%$. It means that there is heteroskedasticity in the conventional bank model so the MSVAR model used must pay attention to the result of this test. The result of the heteroskedastic test for Islamic bank model displays probability $\mathrm{F}$ of 0.0477 which is smaller than the real level of $5 \%$. It means that even in the Islamic bank model there is heteroskedasticity so MS-VAR model used must pay attention to the result of this test. The results of heteroskedastic test are given in Appendices 6 and 7.

\subsubsection{Partial Significance Test}

Partial Significance test is conducted to examine the significance of each variable. Significant indicators on a real level of $5 \%$ for conventional bank model on regime 1 is CREDO with $t$-value of -1.3813 , on regime 2 is IR with t-value of -0.8011 and M2 with t- value of 0.7035 . More complete results can be seen in Appendix 8. Furthermore, significant indicators at the real level of 5\% in the Islamic bank model on regime 1 is BDS with t-value of -0.3103 , on regime 2 is BDS and CA/GDP with t-value of 1.5843 and 1.3554 accordingly. The t-values of each regime in the Islamic bank model can be seen in Appendix 9 .

\subsection{Interpretation of Estimated Results}

From the data used by the author, different results are achieved from the conventional bank model and Islamic bank model. As previously discussed about partial significance of the variables, there are three significant indicators for the conventional model (CREDO in regime 1, IR and M2 in regime 2) and there are two significant indicators for the Islamic model (BSD in regime 1, and BDS and CA/GDP in regime 2).

Table (5) Coefficient Variable of Conventional Bank Model

\begin{tabular}{|c|c|c|}
\hline \multirow{2}{*}{ Variable } & \multicolumn{2}{|c|}{ Coefficient } \\
\cline { 2 - 3 } & Regime 1 & Regime 2 \\
\hline BDK & -12 & -77.05 \\
\hline CARK & -23.32 & -23.62 \\
\hline LDR & -11.57 & 50.20 \\
\hline CRK & -0.19 & 0.52 \\
\hline IR & 0.23 & $\mathbf{- 0 . 0 2}$ \\
\hline IPI & 4.23 & 2.33 \\
\hline INF & 1.01 & 0.76 \\
\hline EXC & 3.44 & 3.87 \\
\hline CREDO & $\mathbf{- 0 . 7 2}$ & 6.40 \\
\hline M2 & 1.45 & $\mathbf{0 . 2 3}$ \\
\hline CA/GDP & -0.08 & 1.95 \\
\hline
\end{tabular}

Note: Ones in bold are significant to the real level of 5\% in accordance with Partial Significance test.

From table 5 we can see that CREDO is the indicator of conventional bank model that has a significant effect on the crises. It means that domestic credit increase of $1 \%$ will lower the ZscoreK value. In other words a $1 \%$ increase in domestic credit will lower the stability of conventional banks by $0.72 \%$. This result is in accordance with the research of Vargas (2009) mentioning that one of the leading crises indicators is domestic credit. In the regime 2 , indicators that have a significant effect on the crises is IR with negative coefficient and M2 with positive coefficient This indicates that a $1 \%$ increase in IR will decrease the value of ZscoreK indicating a decrease in conventional banking stability by $0.02 \%$ while an increase in M2 by $1 \%$ will increase ZscoreK value or increase conventional banking stability by $0.23 \%$.

For the second model, which is the Islamic bank model, the coefficient of each variable can be seen in the table 6 . 
Table (6) Coefficient of Islamic bank model

\begin{tabular}{|c|c|c|}
\hline \multirow{2}{*}{ Variable } & \multicolumn{2}{|c|}{ Coefficient } \\
\cline { 2 - 3 } & Regime 1 & Regime 2 \\
\hline BDS & $\mathbf{0 . 0 5}$ & $\mathbf{0 . 2 1}$ \\
\hline CARS & 12.40 & 12.24 \\
\hline FDR & 41.13 & 40.44 \\
\hline CRS & 0.68 & 0.69 \\
\hline IR & 0.028 & 0.03 \\
\hline IPI & 0.78 & 0.79 \\
\hline INF & 0.11 & 0.12 \\
\hline EXC & 0.82 & 0.84 \\
\hline CREDO & 0.75 & 0.72 \\
\hline M2 & 0.17 & 0.16 \\
\hline CA/GDP & 0.04 & $\mathbf{0 . 0 2}$ \\
\hline
\end{tabular}

Note: Ones in bold are significant to the real level of 5\% in accordance with Partial Significance test.

From Table 6 the variable of the Islamic bank model on regime 1 indicator that is significant at the real level of 5\% is BDS with a positive coefficient value. It means that an increase in an Islamic banking deposit of $1 \%$ will increase the ZscoreS value by $0.05 \%$. In other words, the stability of Islamic banking will also increase by $0.05 \%$. On regime 2 , indicators that are significant at the real level of $5 \%$ are BDS and CA/GDP with positive coefficient values of 0.21 and 0.02 respectively. This means that the increase in Islamic banking deposits in regime 2 by $1 \%$ will increase the stability of Islamic banking by $0.21 \%$ and a $1 \%$ increase in CA/GDP will increase the stability of Islamic banking by $0.02 \%$.

\subsection{Regime Transfer and Transition}

One of the advantages of the MS-VAR method is that the threshold index value is an endogenous variable meaning that the crisis period and the length of the crisis are part of the estimation. The results of the data using OxMetrics software show that there was a shift from regime 1 (quiet period) to regime 2 (crisis period). It can be seen from the transition table matrix of conventional banking model (table 7) that the probability of transition of conventional banking matrix from regime 1 to regime 2 is $5.16 \%$ and the probability of transition matrix from regime 2 to regime 1 is $6.66 \%$. The probability of matrix in regime 1 is
$94.84 \%$ and the probability of matrix in regime 2 is $93.34 \%$. It explains that conventional banking has an uncertain cycle between regimes in which regime 1 (quiet period) and regime 2 (crisis period) have the same probability. Therefore, the policy makers should investigate the indicators that trigger a conventional banking crisis more accurately. Table 7 shows the probabilities of transition matrix.

Transitional shift of matrix regime 1 and regime 2 of conventional banking and Islamic banking have the same cycle where the economic cycle will continue to move at a stable level and there will be times where it will move at an unstable level. It can be seen from the table of transition probability in Islamic banking model from quiet period to crisis period (table 8 ), that the probability matrix from regime 1 to regime 2 is $12.63 \%$ and the probability matrix from regime 2 to regime 1 is $74.08 \%$. On the other hand, when it is in regime 1 the probability matrix is $87.37 \%$ and when it is in regime 2 the probability matrix is $25.92 \%$. This means that the tendency probability of Islamic banking is in regime 1 (quiet period); this can be proven from the result of probability transition regime of Islamic banking matrix, where the probability of transition matrix in regime 1 is greater than the probability of transition matrix in regime 2 , that is between $87.37 \%$ and $25.92 \%$.

Table (7) Matrix Transition Probability Regime of Conventional Bank Model

\begin{tabular}{|c|c|c|}
\hline & Regime 1 & Regime 2 \\
\hline Regime 1 & 0.9484 & 0.0516 \\
\hline Regime 2 & 0.0666 & 0.9334 \\
\hline
\end{tabular}

Source: Author's modification 
Table (8) Matrix Transition Probability Regime of Islamic Bank Model

\begin{tabular}{|c|c|c|}
\hline & Regime 1 & Regime 2 \\
\hline Regime 1 & 0.8737 & 0.1263 \\
\hline Regime 2 & 0.7408 & 0.2592 \\
\hline
\end{tabular}

Source: author's modification

\subsection{Duration and Probability of the Regime}

One of the advantages of using the Markov Switching method is to be able to know the possibility of changes in the economic cycle, either recession, boom or crisis. In addition, this method can also estimate the duration of the period of calm described by regime 1 and the period of crisis described by regime 2 . There are two models in the research; they are conventional bank model and Islamic bank model, where each model has a different result. The difference of this result can be used as a comparison of which bank models have high duration and probability at the time of crisis and which bank model has high duration and probability during a quiet period.

From table 9 it can be noted that the number of observations of conventional banks in regime 1 is 96 and in regime 2 the number is 62 . Regime 1 is the calm period in this conventional bank model and its probability value is 0.5636 . Regime 2 is the crisis period and its probability value is 0.4364 . Then the duration of regime 1 for this conventional bank model is 19.38 months and the duration of regime 2 is 15.01 months. This result indicates that the quiet period of conventional banking is longer compared to its crisis period; 19.38 months versus 15.01 months. The probability values of the quiet period and the crises period of conventional banking are not greatly different. It also can be said that the cycle of quiet period and crisis period of conventional banking will continue to occur.

The second model is the Islamic banking model (table 10). Probability in regime 1 and duration in regime 1 are greater than the ones of regime 2 . The probability in regime 1 is 0.8543 and in regime 2 it is 0.1457 . Duration in regime 1 is 7.91 months and the one in regime 2 is 1.35 months. This result proves that Islamic banking is more stable against banking crisis shocks. The likelihood of crises in Islamic banking is only $14.57 \%$ with a short duration of only about 1.35 months and after that it will return to stability.

Table (9) Regime Duration of Conventional Bank Model

\begin{tabular}{|c|c|c|c|}
\hline & $n O b s$ & Prob & Durasi \\
\hline Regime 1 & 96.0 & 0.5636 & 19.38 \\
\hline Regime 2 & 62.0 & 0.4364 & 15.01 \\
\hline
\end{tabular}

Source: Writer's modification.

Table (10) Regime Duration of Islamic Bank Model.

\begin{tabular}{|c|c|c|c|}
\hline & $n O b s$ & Prob & Durasi \\
\hline Regime 1 & 134.8 & 0.8543 & 7.91 \\
\hline Regime 2 & 23.2 & 0.1457 & 1.35 \\
\hline
\end{tabular}

Source: Writer's modification

\subsection{Crisis Periods in Indonesia}

In Markov switching research, the period of crisis decision is part of the estimation result. And this research uses two equations of models so there is a crisis period of conventional banking model and a crisis period of Islamic banking model.

\subsubsection{Crises Periods of Conventional Banking Model}

The estimation of the crises period of conventional bank model was done based on the movement of the variables in the research. The graph of crisis period of conventional bank model is shown by the results of the classification probability regime of the crisis period. 


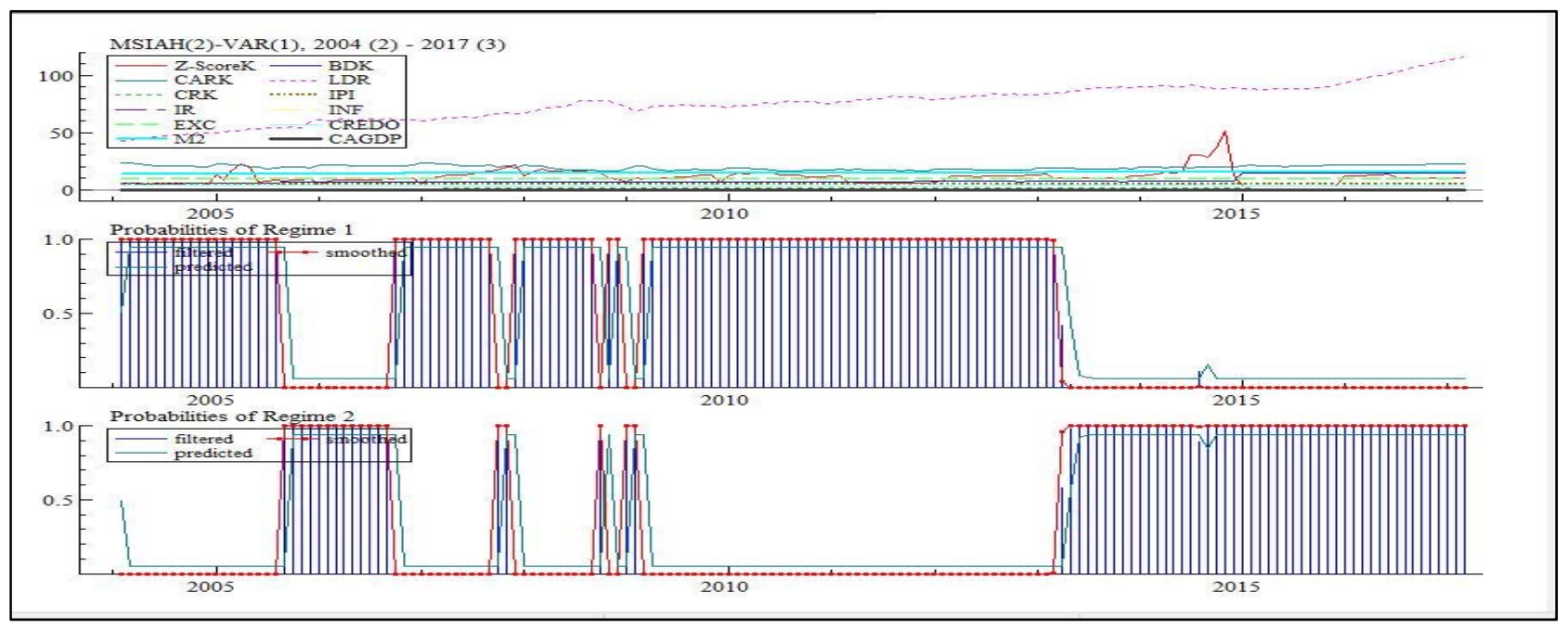

Source: Author's modification.

Figure (3) Classification Probability Regime of the Conventional Banking Model

There are two regimes in the graph; regime 1 and regime 2 . Regime 1 is a quiet period while regime 2 is a crisis period. The quiet period of conventional banking is in accordance with the results of the duration of the regime where the calm period of conventional banking has a longer duration compared with the crisis period, although not greatly different. The period of the conventional banking crisis occurred in the period of September 2005 - September 2006, October 2007 - November 2007, October 2008, January 2009 - February 2009 and April 2013 - March 2017. The longest crisis period is the last period where conventional banking experienced a crisis for about 4 years. This was due to the policy of quantitative easing conducted by the United States to strengthen its economy after the 2008 crisis. However, it had implications for developing countries such as Indonesia. In addition, global economic growth during this period was still slow and not stable after the crisis in 2008. The result of the Chow Breakpoint test shows that the crisis period of conventional banking started in the period of October 2016, as shown in table 11 .

Table (11) Regime Classification of the Conventional Banking Model

\begin{tabular}{|l|l|}
\hline \multirow{4}{*}{ Regime 1 } & $2004: 02-2005: 08$ \\
\cline { 2 - 2 } & $2006: 10-2007: 09$ \\
\cline { 2 - 2 } & $2007: 12-2008: 09$ \\
\cline { 2 - 2 } & $2008: 11-2008: 12$ \\
\hline \multirow{4}{*}{ Regime 2 } & $2009: 03-2013: 03$ \\
\hline & $2005: 09-2006: 09$ \\
\cline { 2 - 2 } & $2007: 10-2007: 11$ \\
\cline { 2 - 2 } & $2008: 10-2008: 10$ \\
\cline { 2 - 2 } & $2009: 01-2009: 02$ \\
\hline
\end{tabular}

Source: Writer's modification.

\subsubsection{Crisis Periods of Islamic Banking Model}

The second model is the Islamic bank model, where the variables used are the micro variables which by definition are the same as those in the conventional bank model and macroeconomic variables which are also the same those of the conventional bank models but have a different result. The estimation of Classification Probability Regime of the crisis period is shown in Figure 4. 


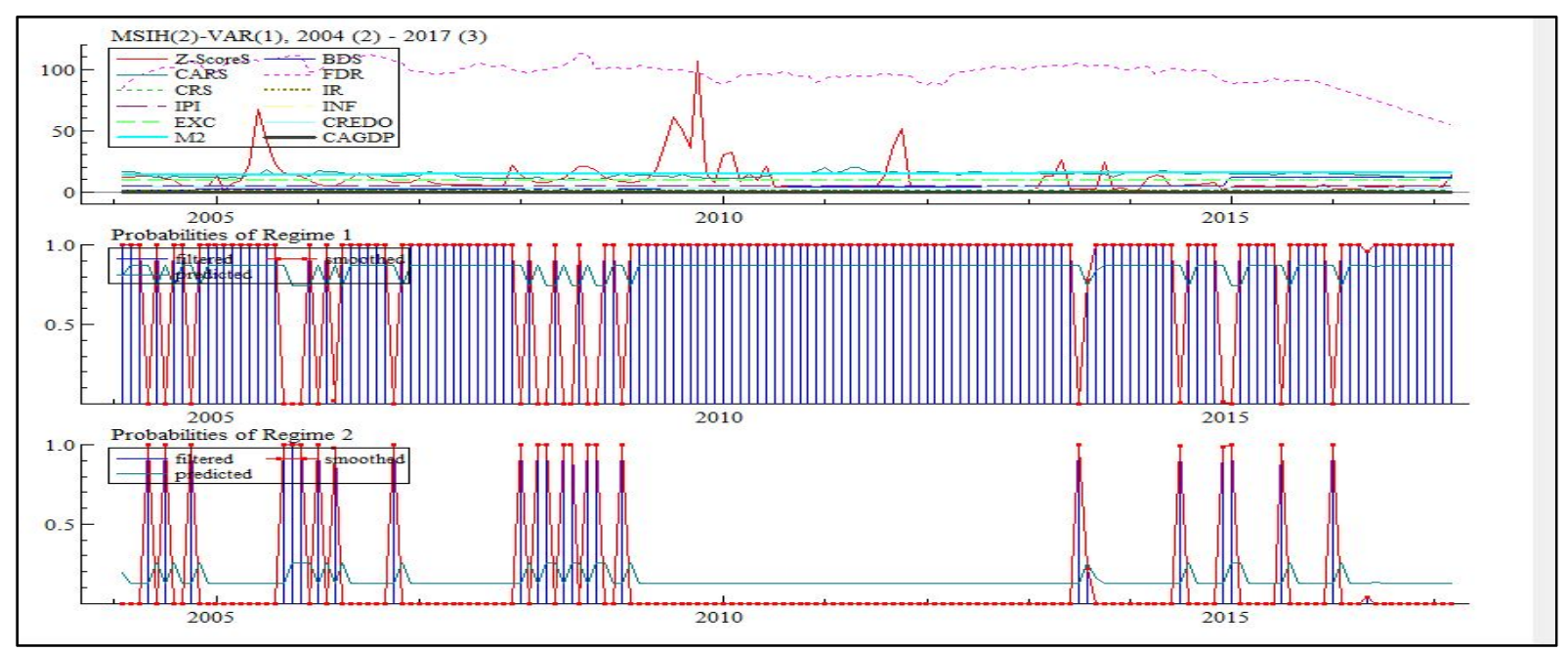

Source: Author's modification.

Figure (4) Classification Probability Regime of Islamic Banking Model

From the graph of the probability of classification of Islamic banking regime we can see that there are several quiet periods and crisis periods in the Islamic banking model and the graph also shows that there are more quiet periods (regime 1) than crisis periods (regime 2) in Islamic banking. It proves that the resilience and stability of Islamic banking to the banking crises and global economic uncertainty is favorable. It can also be seen that there is continuity of Islamic banking crises which is shown by regime 2 that occurred in August 2008 - October 2008. This result is in accordance with the results of the Chow Breakpoint test which illustrates that there is a structural shift in the Islamic banking model that is in the period of August 2008. In summary, the estimation result of Classification Probability Regime of Islamic Banking Model is presented in the table 12.

\section{Conclusion and Recommendations}

\subsection{Conclusion}

The leading indicator for conventional banking in regime 1 is Credit Domestic (CREDO) where the higher the value of CREDO indicates that the conventional banking stability will decrease. Furthermore, significant indicators on regime 2 for conventional banking are Interest Rate (IR) and Money Supply (M2), where an increase in IR will decrease conventional banking stability and an increase in M2 will improve the stability of conventional banking. The leading indicator for the Islamic banking in regime 1 is Bank Deposit (BDS) showing that a $1 \%$ increase of BDS will increase the stability of Islamic banking by $0.05 \%$. In regime two the significant indicators are BDS and Current Account/GDP (CA/ GDP); both have positive coefficients meaning that every $1 \%$ increase of BDS and CA/GDP in a crisis will increase the stability of Islamic banking by $0.21 \%$ and $0.02 \%$ respectively. The longest conventional banking crisis period is April 2013 - March 2017. The longest period of Islamic banking crisis is in January - October 2008.

\subsection{Recommendations}

From the results of the previous discussion and analysis, there authors propose the following recommendations:

1. The research result indicates that there are some leading indicators that can serve as an early warning indicator of a banking crisis. In addition, this study can also detect the transition from quiet period to crisis period, duration of crisis and probability of shocks of a banking crisis. Hence, this should be the attention of the banking and monetary authorities, in this case OJK (Otoritas Jasa Keuangan, i.e. Financial Services Authority) and BI (Bank Indonesia) to formulate policy in anticipating the crises. In addition, other stakeholders should be non-individualistic and not to aggravate the economic situation with speculations that only benefit certain groups. 
2. The economic cycle will continue to fluctuate in the cycles of calm and crisis. Thus, all parties, especially the micro-prudential authority (OJK) and macro-prudential and monetary authorities (BI) should be more aware and act more rapidly in antici- pating the crises. However, it is equally important for other stakeholders not to act individually by simply wanting personal gains but also to be aware of the economic condition and to help improve economic stability.

Table (12) Regime Classification of Islamic Banking Model

\begin{tabular}{|c|c|}
\hline \multirow{18}{*}{ Regime 1} & 2004:02 - 2004:04 \\
\hline & 2004:06 - 2004:06 \\
\hline & 2004:08 - 2004:09 \\
\hline & 2004:11 - 2005:08 \\
\hline & $2005: 12-2005: 12$ \\
\hline & 2006:02 - 2006:02 \\
\hline & 2006:04 - 2006:09 \\
\hline & $2006: 11-2007: 12$ \\
\hline & 2008:02 - 2008:02 \\
\hline & 2008:05 - 2008:05 \\
\hline & 2008:08 - 2008:08 \\
\hline & 2008:11 - 2008:12 \\
\hline & 2009:02 - 2013:06 \\
\hline & 2013:08 - 2014:06 \\
\hline & 2014:08 - 2014:11 \\
\hline & 2015:02 - 2015:06 \\
\hline & 2015:08 - 2015:12 \\
\hline & 2016:02 - 2017:03 \\
\hline \multirow{16}{*}{ Regime 2} & 2004:05 - 2004:05 \\
\hline & 2004:07 - 2004:07 \\
\hline & $2004: 10$ - 2004:10 \\
\hline & 2005:09 - 2005:11 \\
\hline & 2006:01 - 2006:01 \\
\hline & $2006: 03-2006: 03$ \\
\hline & $2006: 10$ - 2006:10 \\
\hline & 2008:01 - 2008:01 \\
\hline & 2008:03 - 2008:04 \\
\hline & 2008:06 - 2008:07 \\
\hline & 2008:09 - 2008:10 \\
\hline & 2009:01 - 2009:01 \\
\hline & 2013:07 - 2013:07 \\
\hline & 2014:07 - 2014:07 \\
\hline & 2014:12 - 2015:01 \\
\hline & 2015:07 - 2015:07 \\
\hline
\end{tabular}

Source: Author's modification. 


\section{References}

Abimanyu, A., \& Imansyah, M. (2008). Sistem pendeteksian dini krisis keuangan di Indonesia [Early warning system for financial crisis in Indonesia]. Yogyakarta, Indonesia: Fakultas Ekonomi, Universitas Gajah Mada.

Alandejani, M., Kutan, A.M., \& Samargandi, N. (2017). Do Islamic banks fail more than conventional banks? Journal of International Financial Markets, Institutions and Money, 50, 135-155.

Ali, S.S. (2007). Financial distress and bank failure: Relevance for Islamic banks. In S. S. Ali \& A. Ahmad (Eds.), Islamic Banking and Finance: Fundamentals and Contemporary Issues (pp. 99-120). Jeddah: Islamic Research and Training Institute (IRTI).

Ascarya, A.S. (2009). Forgotten Root Causes of the Crisis. Paper presented at the Serial Roundtable Discussion on Krisis Keuangan Global dan Outlook Perekonomian Indonesia 2009: Tantangan Bagi Pegawai Bank Indonesia [Serial Roundtable Discussion on The Global Financial Crisis and Indonesia's 2009 Economic Outlook: Challenges for Bank Indonesia Employees], Jakarta, Bank Indonesia. Retrieved from: https://www.researchgate.net/ publication/304782779 FORGOTTEN ROOT CAU SES_OF_THE_CRISIS

Ascarya, A.S. (2015). Determining the Real Causes of Financial Crisis in Islamic Economic Perspective: ANP Approach. Tazkia Islamic Finance and Business Review, 9(2), 109-127.

Ascarya, A.S., Achsani, N.A., \& Yumanita, D. (2007). Towards Integrated Monetary Policy under Dual Financial System: Interest System vs. Profit-and-Loss Sharing System (mimeo). PPSK, Bank Indonesia, Jakarta.

Brooks, D., Kurmanalieva, E., \& Yang, D.Y. (2016). Trade, Trade Finance, and Global Liquidity in Asia; Markov-Switching FAVAR Approach. East Asian Economic Review, 20(3), 339-363.

Caggiano, G., Calice, P., Leonida, L., \& Kapetanios, G. (2016). Comparing logit-based early warning systems: Does the duration of systemic banking crises matter? Journal of Empirical Finance, 37, 104-116.

Chiaramonte, L., Croci, E., \& Poli, F. (2015). Should we trust the Z-score? Evidence from the European Banking Industry. Global Finance Journal, 28, 111131.

Cihák, M., \& Hesse, H. (2008). Islamic banks and financial stability: An empirical analysis (IMF Working Paper No. WP/08/16). Retrieved from: https://www.imf.org/external/pubs/ft/wp/2008/wp0816. pdf
Dabrowski, J.J., Beyers, C., \& de Villiers, J.P. (2016). Systemic banking crisis early warning systems using dynamic Bayesian networks. Expert Systems with Applications, 62, 225-242.

Doumpos, M., Hasan, I., \& Pasiouras, F. (2017). Bank overall financial strength: Islamic versus conventional banks. Economic Modelling, 64, 513-523.

Edison, H.J. (2000). Do Indicators of Financial Crises Work? An Evaluation of an Early Warning System (Board of Governors of the Federal Reserve System, International Finance Discussion Papers, No. 675). Retrieved from: https://www.federalreserve.gov/ Pubs/ifdp/2000/675/ifdp675.pdf

Farooq, M., \& Zaheer, S. (2015). Are Islamic Banks More Resilient during Financial Panics? (IMF Working Paper No. WP/15/41). Retrieved from: https://www.imf.org/ /media/Websites/IMF/importedfull-text-pdf/external/pubs/ft/wp/2015/_wp1541.ashx

Frankel, J.A., \& Rose, A.K. (1996). Currency crashes in emerging markets: An empirical treatment. Journal of international Economics, 41(3/4), 351-366.

Goldstein, M., Kaminsky, G.L., \& Reinhart, C.M. (2000). Assessing Financial Vulnerability: An Early Warning System for Emerging Markets. Washington, D.C.: Institute for International Economics.

Guérin, P., \& Leiva-Leon, D. (2017). Model averaging in Markov-switching models: Predicting national recessions with regional data. Economics Letters, 157, 45-49.

Gujarati, D.N. (2003). Basic Econometrics (4th ed.). New York: McGraw-Hill.

Guleva, V.Y. (2016). The combination of topology and nodes' states dynamics as an early-warning signal of critical transition in a banking network model. Procedia Computer Science, 80, 1755-1764.

Hamdaoui, M. (2016). Are systemic banking crises in developed and developing countries predictable? Journal of Multinational Financial Management, 37$38,114-138$.

Hussein, K. (2010). Bank-level stability factors and consumer confidence - A comparative study of Islamic and conventional banks' product mix. Journal of Financial Services Marketing, 15(3), 259-270.

Ibrahim, M.H., \& Rizvi, S.A.R. (2017). Do we need bigger Islamic banks? An assessment of bank stability. Journal of Multinational Financial Management, 40, 77-91.

Ibrahim, M.H., \& Rizvi, S.A.R. (2018). Bank lending, deposits and risk-taking in times of crisis: A panel analysis of Islamic and conventional banks. Emerging Markets Review, 35, 31-47. 
Imansyah, M.H. (2008). Krisis keuangan di Indonesia, dapatkah di ramalkan? [Financial crisis in Indonesia, can it be predicted?]. Jakarta: Elex Media Komputindo.

Islahi, A. A. (2013). Economic and Financial Crises in Fifteenth-Century Egypt: Lessons From the History. Islamic Economic Studies, 21(2), 71-94.

Kaminsky, G., Lizondo, S., \& Reinhart, C.M. (1998). Leading indicators of currency crises. IMF Staff Papers, 45(1), 1-48.

Kartini, D. (2016, August 9). Perbankan dalam pusaran krisis moneter 1997-1998 [Banking in the whirlwind of the 1997-1998 monetary crisis]. Retrieved from: https://lipsus.kontan.co.id/v2/perbankan/read/320/perba nkan-dalam-pusaran-krisis-moneter

Kimmel, R.K., Thornton Jr., J.H., \& Bennett, S.E. (2016). Can statistics-based early warning systems detect problem banks before markets? The North American Journal of Economics and Finance, 37, 190216.

Krolzig, H.M. (1997). Markov-Switching Vector Autoregressions: Modelling, Statistical Inference, and Application to Business Cycle Analysis. Berlin: SpringerVerlag.

Krugman, P. (1979). A model of balance-of-payments crises. Journal of money, credit and banking, 11(3), 311-325.

Krznar, I. (2004). Currency crisis: Theory and practice with application to Croatia (Croatian National Bank working paper No. w-12). Retrieved from: http://old. hnb.hr/publikac/istrazivanja/w-012.pdf

Kuan, C.M. (2002). Lecture on the Markov Switching Model [Pdf]. Retrieved from: http://homepage.ntu. edu.tw/ ckuan/pdf/Lec-Markov_note.pdf

Lang, M., \& Schmidt, P.G. (2016). The early warnings of banking crises: Interaction of broad liquidity and demand deposits. Journal of International Money and Finance, 61, 1-29.

Meera, A.K.M. (2004). The theft of nations: Returning to gold. Selangor, Malaysia: Pelanduk Pubns Sdn Bhd.

Obstfeld, M. (1996). Models of currency crises with selffulfilling features. European economic review, 40(3-5), 1037-1047.

Ozkan, F.G., \& Sutherland, A. (1995). Policy measures to avoid a currency crisis. The Economic Journal, 105(429), 510-519.

Papanikolaou, N.I. (2018). A dual early warning model of bank distress. Economics Letters, 162, 127-130.
Piger, J. (2009). Econometrics: Models of Regime Changes. In R. A. Meyers (Ed.), Complex Systems in Finance and Econometrics (pp. 190-202). New York: Springer.

Saeed, M., \& Izzeldin, M. (2016). Examining the relationship between default risk and efficiency in Islamic and conventional banks. Journal of Economic Behavior \& Organization, 132(Supplement), 127-154.

Salant, S.W., \& Henderson, D.W. (1978). Market anticipations of government policies and the price of gold. Journal of political economy, 86(4), 627-648.

Saqib, O.F. (2002). Interpreting currency crises: a review of theory, evidence, and issues (Deutsches Institut für Wirtschaftsforschung Discussion Paper No. 303). Retrieved from: http://www.diw.de/documents/ publikationen/73/diw_01.c.38608.de/dp303.pdf

Shah, S.Z.A., \& Bhutta, N.T. (2016). Does Islamic Finance Prevent Financial Crises: A Global Perspective. Journal of Finance, Accounting and Management, 7(2), 31-38.

Stolbov, M. (2015). Anatomy of international banking crises at the onset of the Great Recession. International Economics and Economic Policy, 12(4), 553-569.

Suta, I. P.G.A., \& Musa, S. (2003). Membedah Krisis Perbankan: anatomi krisis dan penyehatan perbankan [Analysis of Banking Crisis: crisis anatomy and banking restructuring]. Jakarta: Yayasan Sad Satria Bhakti.

Tanaka, K., Kinkyo, T., \& Hamori, S. (2016). Random forests-based early warning system for bank failures. Economics Letters, 148, 118-121.

Trad, N., Trabelsi, M.A., \& Goux, J.F. (2017). Risk and profitability of Islamic banks: A religious deception or an alternative solution? European Research on Management and Business Economics, 23(1), 40-45.

Vargas, G.A. (2009). Markov Switching VAR Model of Speculative Pressure: An Application to the Asian Financial Crisis (Masters dissertation). Singapore Management University. Retrieved from: http://ink. library.smu.edu.sg/etd_coll/27

Vermeulen, R., Hoeberichts, M., Vašíček, B., Žigraiová, D., Šmídková, K., \& de Haan, J. (2015). Financial stress indices and financial crises. Open Economies Review, 26(3), 383-406.

Yang, B. (2017). Stock Market Crash, New Market Failure Theory and Extremely Great Economic and Financial Crises. World Review of Political Economy, 8(1), 4-34. 


\section{Appendices}

Appendix (1) Chow Breakpoint Test Result of Conventional Bank

\begin{tabular}{|c|c|c|c|}
\hline \multicolumn{3}{|c|}{ Chow Breakpoint Test: 2006M10 } & \\
\hline \multicolumn{4}{|c|}{ Null Hypothesis: No breaks at specified breakpoints } \\
\hline \multicolumn{3}{|c|}{ Varying regressors: All equation variables } & \\
\hline F-statistic & 2.137928 & Prob. F(12,108) & 0.0200 \\
\hline Log likelihood ratio & 28.13338 & Prob. Chi-Square(12) & 0.0053 \\
\hline Wald Statistic & 25.65513 & Prob. Chi-Square(12) & 0.0120 \\
\hline
\end{tabular}

Appendix (2) Chow Breakpoint Test Result of Islamic Bank

\begin{tabular}{|c|c|c|c|}
\hline \multicolumn{3}{|c|}{ Chow Breakpoint Test: 2005M08 } & \\
\hline \multicolumn{4}{|c|}{ Null Hypothesis: No breaks at specified breakpoints } \\
\hline \multicolumn{3}{|c|}{ Varying regressors: All equation variables } & \\
\hline F-statistic & 1.984528 & Prob. F(12,108) & 0.0324 \\
\hline Log likelihood ratio & 26.30274 & Prob. Chi-Square(12) & 0.0097 \\
\hline Wald Statistic & 23.81434 & Prob. Chi-Square(12) & 0.0216 \\
\hline
\end{tabular}

Appendix (3) Heteroskedasticity Test of Conventional Bank Model

\begin{tabular}{|c|c|c|c|}
\hline \multicolumn{4}{|c|}{ Heteroskedasticity Test: Breusch-Pagan-Godfrey } \\
\hline F-statistic & 3.709031 & Prob. F(11,120) & $\mathbf{0 . 0 0 0 1}$ \\
\hline Obs*R-squared & 33.49213 & Prob. Chi-Square(11) & 0.0004 \\
\hline Scaled explained SS & 200.8152 & Prob. Chi-Square(11) & 0.0000 \\
\hline
\end{tabular}

Note: The ones printed in bold are significant at the real level of $5 \%$

\section{Appendix (4) Heteroskedasticity Test of Islamic Bank Model}

\begin{tabular}{|c|c|c|c|}
\hline \multicolumn{5}{|c|}{ Heteroskedasticity Test: Breusch-Pagan-Godfrey } \\
\hline F-statistic & 1.885420 & Prob. F(11,120) & $\mathbf{0 . 0 4 7 7}$ \\
\hline Obs*R-squared & 19.45173 & Prob. Chi-Square(11) & 0.0535 \\
\hline Scaled explained SS & 86.64045 & Prob. Chi-Square(11) & 0.0000 \\
\hline
\end{tabular}

Note: The ones printed in bold are significant to the real level of $5 \%$

Appendix (5) Partial Significance Test of Conventional Bank Model

\begin{tabular}{|c|c|c|}
\hline \multirow{2}{*}{ Indicator } & \multicolumn{2}{|c|}{ T-Value } \\
\cline { 2 - 3 } & Regime 1 & Regime 2 \\
\hline BDK & -164.4160 & -1307.6288 \\
\hline CARK & -1307.5616 & -498.9905 \\
\hline LDR & -843.3401 & 4541.8006 \\
\hline CRK & -568.9021 & 1746.0729 \\
\hline IR & 14.1730 & $\mathbf{- 0 0 . 8 0 1 1}$ \\
\hline IPI & 68.5322 & 031.0381 \\
\hline INF & 04.1477 & 02.4186 \\
\hline EXC & 08.9453 & 07.3939 \\
\hline CREDO & $\mathbf{- 0 1 . 3 8 1 3}$ & 16.8523 \\
\hline M2 & 03.3259 & $\mathbf{0 0 . 7 0 3 5}$ \\
\hline CAGDP & -04.9888 & 03.1810 \\
\hline
\end{tabular}


Appendix (6) Partial Significance Test of Islamic Bank Model.

\begin{tabular}{|c|c|c|}
\hline \multirow{2}{*}{ Indicator } & \multicolumn{2}{|c|}{ T-Value } \\
\cline { 2 - 3 } & Regime 1 & Regime 2 \\
\hline BDS & $\mathbf{- 0 . 3 1 0 3}$ & $\mathbf{1 . 5 8 4 3}$ \\
\hline CARS & 105.9203 & 106.0090 \\
\hline FDR & 133.6744 & 131.2782 \\
\hline CRS & 06.2878 & 06.3288 \\
\hline IR & 01.9758 & 02.0529 \\
\hline IPI & 09.1677 & 09.1323 \\
\hline INF & 02.1830 & 02.2349 \\
\hline EXC & 06.1961 & 06.3273 \\
\hline CREDO & 05.4398 & 05.2121 \\
\hline M2 & 04.1772 & 04.0700 \\
\hline CAGDP & 02.9988 & $\mathbf{0 1 . 3 5 5 4}$ \\
\hline
\end{tabular}

Appendix (7) Heteroskedasticity Test Islamic Bank Model

\begin{tabular}{|c|c|c|c|}
\hline \multicolumn{4}{|c|}{ Heteroskedasticity Test: Breusch-Pagan-Godfrey } \\
\hline F-statistic & 1.885420 & Prob. F(11,120) & $\mathbf{0 . 0 4 7 7}$ \\
\hline Obs*R-squared & 19.45173 & Prob. Chi-Square(11) & 0.0535 \\
\hline Scaled explained SS & 86.64045 & Prob. Chi-Square(11) & 0.0000 \\
\hline
\end{tabular}

Note: Bold is significant at $5 \%$

Appendix (8) Partial Significance Test of Conventional Bank Model

\begin{tabular}{|c|c|c|}
\hline \multirow{2}{*}{ Indicator } & \multicolumn{2}{|c|}{ T-Value } \\
\cline { 2 - 3 } & Regime 1 & Regime 2 \\
\hline BDK & -164.4160 & -1307.6288 \\
\hline CARK & -1307.5616 & -498.9905 \\
\hline LDR & -843.3401 & 4541.8006 \\
\hline CRK & -568.9021 & 1746.0729 \\
\hline IR & 14.1730 & $\mathbf{- 0 0 . 8 0 1 1}$ \\
\hline IPI & 68.5322 & 31.0381 \\
\hline INF & 04.1477 & 02.4186 \\
\hline EXC & 08.9453 & 07.3939 \\
\hline CREDO & $\mathbf{- 0 1 . 3 8 1 3}$ & 16.8523 \\
\hline M2 & 03.3259 & $\mathbf{0 0 . 7 0 3 5}$ \\
\hline CAGDP & -04.9888 & 03.1810 \\
\hline
\end{tabular}

Appendix (9) The Partial Significance of Islamic Bank Model

\begin{tabular}{|c|c|c|}
\hline \multirow{2}{*}{ Indikator } & \multicolumn{2}{|c|}{ T-Value } \\
\cline { 2 - 3 } & Regime 1 & Regime 2 \\
\hline BDS & $\mathbf{- 0 . 3 1 0 3}$ & $\mathbf{1 . 5 8 4 3}$ \\
\hline CARS & 105.9203 & 106.0090 \\
\hline FDR & 133.6744 & 131.2782 \\
\hline CRS & 06.2878 & 06.3288 \\
\hline IR & 01.9758 & 02.0529 \\
\hline IPI & 09.1677 & 09.1323 \\
\hline INF & 02.1830 & 02.2349 \\
\hline EXC & 06.1961 & 06.3273 \\
\hline
\end{tabular}


Irfan Nurfalah is currently Transactional Banking Assistant at Bank BNI Syariah since 2016 until now. Previously, he was Fundraiser in Inisiatif Zakat Indonesia in 2016, and Research Assistant in SMART Consulting in 2016. He graduated with bachelor degree in Islamic Economics from STEI Tazkia in 2015.

E-mail: irfannurfalah@gmail.com

Aam Slamet Rusydiana is currently working as researcher at SMART Consulting. He has more than 60 research publications like journal articles, proceedings, books in Islamic Economics and Finance topics. He has delivered lectures in many research methods workshop in many institutions and universities around Indonesia. He completed his bachelor degree in STEI Tazkia and Master Degree in Ibnu Khaldun University.

E-mail: aamsmart@gmail.com

Nisful Laila is currently Vice Dean for Research, Community Services and Partnership Affairs in Faculty of Economics and Bussiness, Airlangga University. Her research interests are in Islamic Finance especially Islamic Bonds. She has a bachelor degree in management science from Airlangga University, and commerce master degree from University of New South Wales and a doctorate from Airlangga University. She has produced a number of publications like journal articles conference papers.

E-mail: nisful.laila@feb.unair.ac.id

Eko Fajar Cahyono is a faculty member at the Faculty of Economics and Business, Airlangga University since 2014. He has published a number of articles in national and international journals. He has participated in many conferences, seminar, and workshops. He obtained his bachelor's and master's degree in economics from Brawijaya University.

E-mail: ekofajarc@feb.unair.ac.id 


\title{
التحذير المبكرمن الأزمات المصرفية في النظام المالي المزدوج في إندونيسيا: مقاربة ماركوف للتحويل
}

\author{
عرفان نورفلة"، وعام سلامت رشديانا ** ونصفل ليلى و إيكو فجركايونو

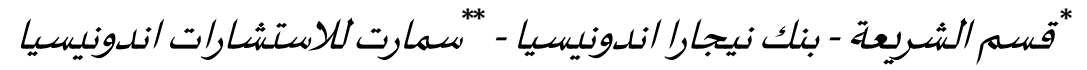

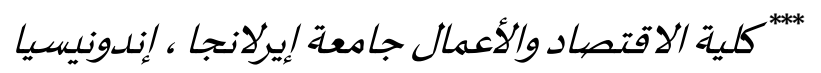

\begin{abstract}
المستخلص. تهدف هذه الدراسة إلى الكشف عن المؤشرات المبكرة التي تسبب الأزمات المصرفية في

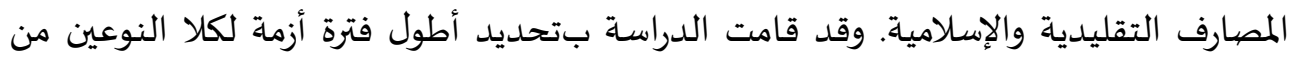

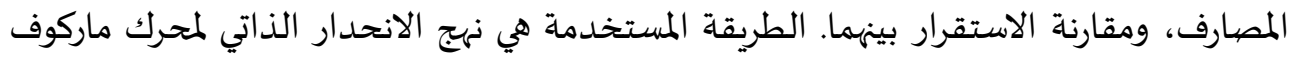
(MS-VAR)

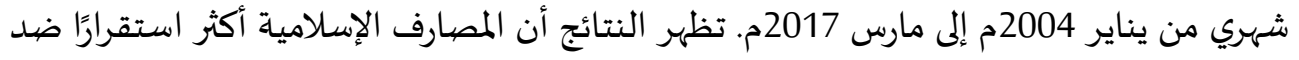

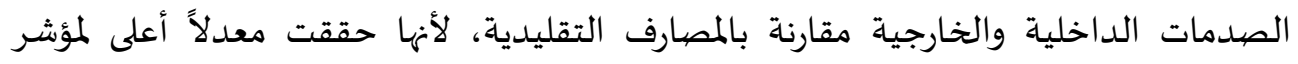
(Z-score)

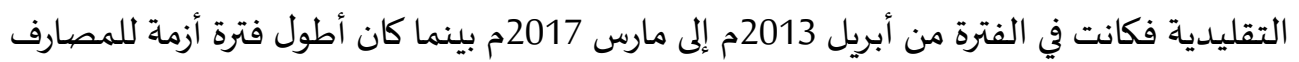
الإسلامية في الفترة ما بين يناير 2008م وأكتوبر 2008م. الكلمات الدَّالة: الإنذار المبكر، الأزمات المصرفية، مقاربة ماركوف للتحويل. تصنيف L27, L4:KAUJIE
\end{abstract}

